such nomination shall be valid unless it be supported in writing by twelve Members of the College and accompanied by the nominee's written consent to serve if elected.

\section{Regulation XIX THE COUNCIL}

3. Not less than four of the twelve elected Members of Council shall be elected or re-elected each alternate year subject to the overall condition that no elected member shall serve on Council for more than six years in that capacity without a break of at least one year. At its first meeting in each alternate College year after the name of the President for the next ensuing College year has become known, the Council shall nominate for election to the Council four or more Members of the College. Any nominee who is proposed and seconded and gives his consent in writing to serve shall be validly nominated. Any twelve
Members of the College may make nominations in writing at any time between the first day of January in each alternate year and the date which is four clear weeks after the meeting of the Council at which its nominations are made. Nominations other than those made by the Council shall be lodged with the Registrar and accompanied by the written consent of the candidate to serve if elected. Should there be more nominations than vacancies, an election shall be held by ballot of the Members of the College. The ballot paper shall not indicate the method of nomination or the names of those nominating. If the number of nominees does not exceed the number of vacancies, these nominees shall be declared elected at the first meeting, whether of the Council or of the Executive and Finance Committee, after the expiry of the period of four clear weeks in this paragraph referred to.

\title{
Elections to the Fellowship, 1989
}

The Members listed below have been elected as Fellows of the College by the Court of Electors:

Dr M. K. F. Al-Farekh, Dr M. Asaduzzaman (Dr M. A. Zaman on Membership list), Dr K. Attaullah, Dr G. M. Baird, Dr H. Bevan-Jones, Dr J. S. Bolton, Professor N. Bohacek, Dr C. K. Bridgett, Dr G. B. Cassano, Dr D. Chiswick, Dr R. V. Cope, Dr J. Cordingly, Dr M. Dineen, Dr W. M. Donovan, Dr M. H. S. El-Badramany, Dr O. E. F. A. El-Rufaie, Dr G. Forrest, Dr J. W. Garry, Dr I. M. Ghany, Dr S. M. Grant, Dr K. C. Gupta, Dr J. Handley, Dr S. W. Hettiaratchy, Dr F. H. Hocking, Dr S. C. Hollins, Dr L. I. M. Homewood, Dr E. Hughes-Roberts, Dr A. V. Jablensky, Dr H. D. James, Dr S. R. N. James, Dr
G. K. R. Jamieson, Dr B John, Dr T. Kay, Dr L. P. Kok, Dr J. W. S. Kraemer, Dr L. McCurdy, Dr M. N. McGuinness, Dr P. C. McLean, Dr D. C. Mawson, Dr L. M. Measey, Dr J. B. Murphy, Dr R. Nada Raja, Dr H. Nichol, Dr K. P. O'Brien, Dr C. V. Oppenheimer, Dr G. C. Owens, Dr J. Owens, Dr H. Petursson, Dr J. C. Powell, Dr G. J. Pryce, Dr V. A. Rama Rao, Dr M. A. Reveley, Dr J. R. Robertson, Dr N. P. Sebaratnam, Dr W. A. Saunders, Dr E. C. Sheldrick, Dr T. H. Singh, Dr A. H. W. Smith, Professor G. Solomon, Dr F. E. Subotsky, Dr R. L. Symonds, Dr G. I. Szmukler, Dr K. Tareen, Dr P. J. Taylor, Dr G. Theano, Dr J. E. Thomas, Dr P. J. Tubridy, Dr M. Vallance, Dr J. M. Werner, Dr G. C. P. Wijesinghe, Dr L. M. Winkley, Dr J. Wood. 